\title{
PERCEIVED IN-GROUP DENSITY AND PSYCHOLOGICAL ADJUSTMENT IN A SAMPLE OF NORTHERN IRISH CATHOLICS AND PROTESTANTS
}

\author{
John MALLET, Christopher Alan LEWIS ${ }^{1}$, Ed CAIRNS \\ ${ }^{1}$ Glyndwr University \\ Mold Road, Wrexham, Wales, LL11 2AW \\ Email: ca.lewis@glyndwr.ac.uk
}

\begin{abstract}
The "contact hypothesis" suggests that desegregation is good for minority group members, but this view has been challenged by studies describing a so-called "ethnic density effect". This study examined the possibility of an "ethnic density effect" in the context of historical ethno-religious segregation in Northern Ireland. It was hypothesised that the "ethnic density effect" is not simply the result of structural variables, such as ethnic population mix at local community level, but also on individual perceptions of area based ethno-religious group density, perceptions of their local group status and their levels of in-group identification or solidarity. Data from 1000 randomly selected participants were tested for ethno-religious group invariance in the prediction of psychological adjustment, as measured by the General Health Questionnaire (GHQ-12). Results indicated a small direct "ethnic density effect" based on perceptions of religious mix at local level $(\mathrm{p}<.05)$. Ethno-religious differences were observed in the relationships between perceived ethnic density and perceived discrimination $(p<.05)$. The "ethnic density effect" reported in some cultural contexts was evident in Northern Ireland and this has implications for policy makers concerned with community relations.
\end{abstract}

Key words: ethnic density effect, General Health Questionnaire, segregation, Northern Ireland

\section{INTRODUCTION}

One of the original ideas behind the "contact hypothesis", now thought of as primarily concerned with changing intergroup attitudes was that minority group members would benefit from desegregation, particularly in terms of increased self-esteem and general psychological wellbeing (Allport, 1954). This general conclusion, that desegregation is good for minority group members, has been challenged by evidence in both the psychiatric epidemiological and social psychological literatures describing a so-called "ethnic density effect" in different cultural contexts (Halpern, 1993; Halpern, Nazroo, 2000; Neeleman, Wessely, 1999; Sam, 1998; Smaje, 1995).

This work suggests that: “... people who live in areas where the population reflects their particular social attributes (ethnic or social status) tend to experience lower rates of mental illness, than those who live in areas where their attributes are atypical." (Smaje, 1995, p. 254).

For example, a study in Britain demonstrated an inverse relationship between the proportion of non-white ethnic minorities in electoral wards in London and the incidence of schizophrenia in these groups (Boydell et al., 2001). These results were not explained 
by deprivation. Instead, it was suggested that drawing upon locally embedded social capital within one's own ethnic in-group might alleviate sources of stress such as overt discrimination, institutional racism or inequality. These findings support work by Halpern and Nazroo (2000) who reported a modest relationship between levels of reported psychiatric symptoms and in-group density. Smaje (1995) also found moderate associations between socio-economic status (SES), ethnic concentration and health. Neeleman and Wessely (1999) found similar associations between ethnic density and suicide rates and Lackland Sam (1998) showed a similar relationship between ethnic density and life satisfaction.

Theoretical explanations of the psychological mechanisms underpinning ethno-religious group density effects have focused on the protective effects of enhanced social cohesion and social support from the direct or indirect consequences of discrimination, ethnic or racial harassment, and feelings of low status stigma (Bécares, Nazroo, 2009; Bécares et al., 2012; Halpern, Nazroo, 2000; Pickett, Wilkinson, 2008; Smaje, 1995). Work drawing on social psychology has offered some interesting theoretical explanations for "ethnic density effects". Postmes and Branscombe (2002) examined the impact of long-term racial segregation on group identification and social categorisation processes in a sample of African-Americans. The authors specifically modelled the mediating effects of group identification and social categorisation in the relationship between racial composition and psychological wellbeing. In social identity theory, group identification and social categorisation are central to understanding of the effects of inter-group relations on wellbeing
(Branscombe, Schmitt, Harvey, 1999; Tajfel, Turner, 1986). These constructs may partially account for the impact of inter-group contact and integration (Hewstone, Brown, 1986). Postmes and Branscombe's (2002) data supported a model suggesting that racially segregated contexts are associated with individual feelings of acceptance by other ingroup members, and to a lesser extent of rejection by members of the out-group. Ingroup acceptance and out-group rejection in turn influenced identification with the ingroup and this strongly predicted psychological wellbeing (a measure of self-esteem). The authors concluded that segregated environments offer in-group support and acceptance, “... thereby protecting self-esteem against possible perils of rejection by a powerful out-group" (p. 735).

Karlsen, Nazroo, and Stephenson (2002) have argued that a key feature in the relationship between ethnicity, health and residential environment, including ethnic ingroup density, is the way in which ethnic identity may lead to a stronger sense of community, which in turn can offer psychological protection in areas where large numbers share the same identity. Conversely, being situated in an area where one's identity is not shared with the majority may have detrimental psychological consequences. In this context, identification with the in-group may therefore exert a moderating influence in the relationship between ethnic density and psychological health. If the relationship between ethnic density and psychological adjustment is contingent upon the level of in-group identification then one would expect the relationship between ethnic density and psychological wellbeing to be positive in situations where identities are strong and close to zero where identities are weak. In effect, the "eth- 
nic density effect" may be contingent upon levels of in-group identification. In this context it is interesting to ask whether in-group identification moderates the effects of ethnic density on psychological wellbeing. This moderating effect can be tested by specifying an identification by ethnic density interaction in the prediction of psychological wellbeing.

The model offered by Postmes and Branscombe (2002) and the ideas suggested by Karlsen et al. (2002) challenge some of the general assumptions derived from the "contact hypothesis" by suggesting that segregation may actually exert positive influences on the individual. The original idea, that segregation is undesirable, stems partly from evidence linking it to socio-economic differentials in the structural characteristics of segregated and integrated environments. For example, African Americans living in integrated environments in the US tend to be less deprived than their counterparts in segregated environments (Sigelman, Welch, 1991).

Northern Ireland is an interesting place in which to examine "ethnic density effects" because of historical ethno-religious residential segregation, particularly in areas of lower economic standing (Poole, Doherty, 1996). That being the case, then any "ethnic density effects" would appear to be somewhat counter-intuitive given the now well documented links between socio-economic conditions and health (e.g., Kennedy et al., 1998). Ethnically segregated environments may actually be depriving individuals of some of the known predictors of wellbeing such as standard of living, social status, and access to services (Karlsen, Nazroo, Stephenson, 2002; Nazroo, 1998; Ross, 2000). For this reason, there is also a need to separate out the potential effects of segregation and socio-economic status on mental wellbeing.

\section{CONTEXT OF THE PRESENT STUDY}

Northern Ireland contains two main ethnoreligious groups (Catholics and Protestants) sharing a relatively small geographic space. These two groups live in largely segregated areas with ethno-religious segregation being more pronounced in areas of high socioeconomic disadvantage (Poole, Doherty, 1996). Northern Ireland is a particularly interesting place to study "ethnic density effects" for two reasons. The first reason is that in Northern Irish society as a whole the two groups, Catholics and Protestants, are close to parity, approximately 40 and 50 percent, respectively of the total population. Residential segregation occurs at various levels, from geographical east - west imbalances to more local neighbourhood level segregation. The terms numerical "majority" and "minority" can therefore be applied to both groupings depending on the geography and the level of analysis (i.e., 582 government electoral wards, the 5022 smaller census output areas, or the 46000 unit postcode levels). Further, neither group can be considered an immigrant group, and both groupings are predominantly white, Christian and speak English. Smaje (1995) argues that socio-economic differentials across groups may be indicative of minority status, which has been documented as a risk factor in mental health studies (see Halpern, 1993 for a review). It is less clear whether socioeconomic factors and minority group status (perceived or otherwise) uniquely predict mental health outcomes or whether one is simply a proxy for the other. 
The second reason is that in Northern Ireland the "contact hypothesis" has been used to underpin much of the community relations policy of the British government over the last twenty years. This means that, in order to foster peace, the government has actively encouraged greater levels of contact between Catholics and Protestants in educational and in residential settings (see Cairns, Hewstone, 2002 for a review). Evidence that some aspects of intergroup contact in Northern Ireland are detrimental to psychological wellbeing would therefore have important policy implications.

\section{Ethnic Density Research in Northern Ireland}

Two studies have produced evidence concerning the "ethnic density effect" in Northern Ireland. Cairns (1988) reported a religion by social class interaction in general psychological adjustment using GHQ-12 (Goldberg, Williams, 1988) scores in a random sample of 581 Northern Irish adults. This study defined the Catholic group as the numerical minority in Northern Ireland as a whole and reported that psychological wellbeing was positively associated with social class for the Protestant majority, and negatively associated with social class for the Catholic minority group. One explanation offered alluded to possible "ethnic density effects" in the context of the Northern Ireland conflict.

"...Catholics in the upper social classes are more likely to live in integrated housing complexes where indeed they are likely to form a local minority and perhaps feel thus more vulnerable. Lower social class Catholics are more likely, however, to live in segregated housing areas where they form the lo- cal majority and perhaps feel less vulnerable." (Cairns, 1988, p. 235).

Mallett, Cairns, and Bunting (2002) concluded that, among 493 Northern Irish parents, minority status was not related to GHQ12 scores. The authors however noted design limitations in their study, firstly with religious minority status being inferred from population ratios aggregated at electoral ward level, and secondly, as this study was based on one district council area of Northern Ireland where the Catholic population experienced numerical superiority by a ratio of $77: 23$. This compares to the Northern Ireland wide sample analysed by Cairns (1988), where Protestants formed the numerical majority by a ratio of 56:44. In addition, although Catholics formed the numerical majority in Mallett et al.'s (2002) study, their socio-economic status relative to Protestants was suggestive of minority status.

\section{THE PRESENT STUDY}

In the two existing Northern Ireland studies (Cairns, 1988; Mallett et al., 2002), both "ethnic density" and inequality/discrimination were operationalised using area-based structural variables. This is typical of the work on the "ethnic density effect", where one notable lacuna is any attempt to test the central hypothesis using anything other than structural variables. In other words, the hypothesised stressors (perceived minority group status, perceived discrimination) and variables, which might moderate them (ingroup solidarity), have yet to be included in a study of "ethnic density effects". In the US, a wealth of research data has demonstrated the negative consequences of discrimination on psychological functioning. For example, studies have highlighted the 
relationships between perceived discrimination and psychological distress, depression and general anxiety (Kessler, Mickelson, Williams, 1999). Major and O'Brien (2005) have reviewed perceived discrimination under an identity threat model of stigma.

However, some studies have begun to suggest that individual characteristics may be more important than area-level characteristics in terms of health (Karlsen, Nazroo, Stephenson, 2002; Postmes, Banscombe, 2002). This study attempts to regress psychological wellbeing onto three operationalised psychological variables, namely: perceived in-group density, perceived discrimination/inequality against the in-group and level of in-group identification in the context of the two predominant ethno-religious groups in Northern Ireland. The study em- ployed structural equation modelling techniques to control for the effects of SES in assessing whether perceptions of in-group density are associated with psychological wellbeing (see hypothetical model presented in Figure 1).

Of particular interest is whether the structural parameters in the model are invariant across the two main religious groupings or whether different processes are occurring at group level that affect the relationships between perceptions of in-group density, own group identification, feelings of discrimination against own group and psychological wellbeing. Research on "ethnic density effects" would lead to the expectation that high levels of in-group density would be directly associated with positive mental health $\left(\beta_{4}\right)$, controlling for the effects of SES.

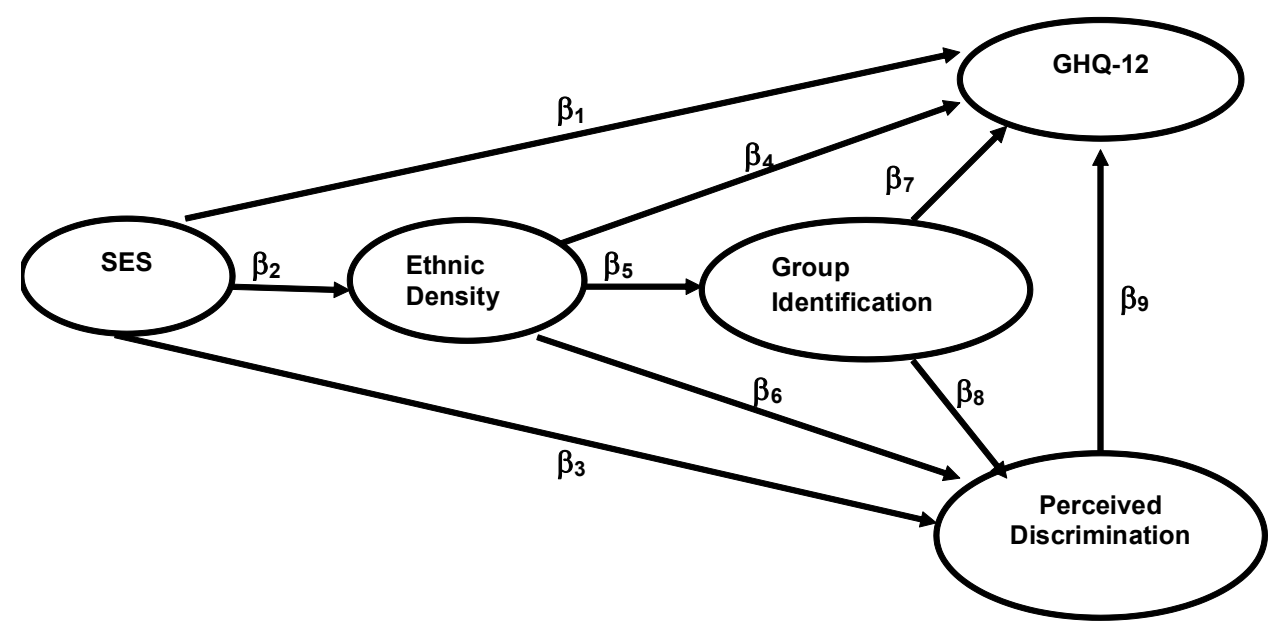

Figure 1. Hypothesised path model of the influence of SES, ethnic density, group identification and perceived discrimination on GHQ-12 
Further, the study investigates the possibility that in-group density relates to feelings of in-group identification/solidarity $\left(\beta_{5}\right)$, as noted by Postmes and Branscombe (2002) and to perceptions of discrimination against the in-group $\left(\beta_{6}\right)$, and whether these perceptions in turn relate to psychological adjustment scores $\left(\beta_{7}-\beta_{\mathrm{o}}\right)$. It is not clear from the literature whether integrated or segregated environments per se affect feelings of discrimination against the in-group. Indeed, such feelings may well be contingent upon perceptions of group status (e.g., majority/minority or equal partners) and inter-group relationships (e.g., collaborative/ competitive or independent/inter-dependent). In addition, to test whether in-group identification moderates the relationship between ethnic density and GHQ-12, an interaction term (identification $\mathrm{x}$ density) was specified in the model.

In summary, the present study tested a model in which levels of social identification with one's in-group and perceptions of discrimination/inequality against the in-group mediate the links between SES, ethnic density and psychological wellbeing. The possible moderating effect of social identification was also tested. Finally, a key question was whether these relationships are invariant across the two ethno-religious groups in Northern Ireland.

\section{METHOD}

\section{Sampling frame}

The Northern Ireland Register of Electors (2000) was used as the sampling frame. The register is inclusive of all individuals nominated on electoral registration forms returned in September 1999. The register is compiled on Local Government District (LGD) of which there are 26 in Northern Ireland. The register was considered accurate given that registration is compulsory and that it is updated on an annual basis.

\section{Sampling Design}

The survey was implemented in 2001 using a probability based stratified random sample using probability proportionate to size (PPS) from each of the 26 LGD's electoral wards were randomly selected (10 in Belfast and two in each of the other 25 LGD's). From each of the selected electoral wards, individuals were selected by means of a simple random sample. The survey aimed to generate an achieved sample of 1000.

\section{Response Rate}

1585 addresses were issued to interviewers to obtain 1000 interviews, yielding an effective response rate of $63 \%$.

\section{Achieved Sample}

1000 adults aged 18 or over were interviewed in their own homes during the period April - end May 2001 as part of a Northern Ireland Social Omnibus Survey. The respondents' age ranged from 18-89 years (Mean $=49.29, \mathrm{SD}=18.8$ ). The sample comprised $42 \%$ male and $58 \%$ female respondents with $48 \%$ stating their religion as Protestant and $41 \%$ as Catholic. A small number refused to answer the question on religious affiliation with $3 \%$ stating their religion as "none" and $2 \%$ as "other". These respondents were subsequently dropped from the main analyses. 


\section{Measures}

Demographic variables were used for descriptive purposes (i.e., sex, age, self-reported religious affiliation). The study was only concerned with the two main ethno-religious groups in Northern Ireland (Catholic and Protestant). The term "Protestant" was used to describe non-Catholic Christians in Northern Ireland and consisted of a number of denominations including Presbyterian, Church of Ireland, Anglican, Episcopalian, Baptist, Methodist, Free Presbyterian and others.

Socioeconomic Status (SES): This was assessed as a composite of two questions relating income and occupation. Income was defined as total household income before tax /national insurance contributions and was on a 10-point scales ranging from 1 (Less than $£ 60$ per week) to 10 (more than $£ 770$ per week). Occupational status was assessed using the UK Standard Occupation Classification (2000). Those not in paid work were scored lowest as 1 and scores ranged from 2 (elementary occupations) to 10 (mangers and senior officials). SES was then assessed as a summated composite with higher scores indicative of higher SES.

Perceived In-group Density: Perceived ingroup density was assessed by measuring perceptions of the degree of out-group clustering in the participant's neighbourhood. The questions were:

1) How many of your close neighbours are of a different religion to you / are from the other community?

2) In the area where you live, how many of the people do you think are of a different religion to you? / from the other community?
3) How often do you see members of the other community in this area?

In addition, respondents were asked to guess the percentage of Protestants and Catholics living in their local area. This was measured on a continuous scale (range 0$100 \%$ ). Responses were then categorised as $0-25 \%, 26-50 \%, 51-75 \%$, and $76-100 \%$. Following confirmatory factor analysis using LISREL 8.7, all four items were treated as ordinal and summated to form a quasi-interval perceived ethnic density score where a high score indicated a high level of in-group density.

Identification with the In-group: Ingroup identification was assessed using five items from the Group Identification Scale (Brown et al., 1986). Each item was responded to on a five-point Likert scale. An example item is:

"Would you say you are a person who:

1) considers the Catholic/Protestant community important?

2) identifies with the Catholic/Protestant community?

3) feels strong ties with the Catholic/Protestant community?

4) glad to belong to the Catholic/Protestant community?

5) sees himself/herself as belonging to the Catholic/Protestant community?

Again, Likert responses to items were summated in an overall religious community identification scale where a high score was indicative of high levels of in-group identification.

Perceived Discrimination/Inequality Against the In-group:Three Likert scale items were included as indicators of perceived discrimination/inequality. These required respondents to indicate their level of satisfaction with: 
1) the way jobs are distributed between the two main communities in Northern Ireland.

2) the way political power is distributed.

3) the relative standard of living of one's in-group relative to the out-group.

Once more, items were summated in a single scale where a high score indicated high expressed dissatisfaction or high perceived discrimination/inequality.

Psychological Wellbeing: Respondents were asked to complete the GHQ-12 (Goldberg, Williams, 1988). It is designed to focus on breaks in normal mental functioning and on the emergence of symptoms of mental distress. Using the Likert method of item scoring $(0,1,2,3)$ the total score for the GHQ-12 ranged from $0-36$ with higher scores indicative of poorer psychological wellbeing.

\section{Statistical Analyses}

All scale items relating to the underlying constructs were initially subject to confirmatory factor analytic modelling using LISREL 8.7 (Jöreskog, Sörbom, 2004). The GHQ-12 contains six positively and six negatively worded items. It was assumed that the GHQ-12 measured one underlying construct pertaining to psychological functioning (all items) and two so-called "method" factors related to item directionality (positive or negative). A single measurement model with seven hypothesised latent variables was simultaneously fitted to a sample of Protestants $(\mathrm{n}=480)$ and Catholics $(\mathrm{n}=412)$ using separate group covariance matrices under the Maximum Likelihood method. Model fit was assessed using the Satora-Bentler Likelihood Ratio Test $\left(\mathrm{S}-\mathrm{B} \chi^{2}\right)$, the Root Mean Square Error of Approximation (RMSEA; Steiger, 1990) and other fit indices.
Items were summed into composite scale scores using the measurement model specifications outlined in Table 1 in order to generate descriptive statistics and test for religious group differences on the scaled variables.

\section{Path Analysis Using Structural Equation Modelling}

Composite scores were subsequently entered into a path analysis using LISREL 8.7 to test for invariance in regression paths ( $\beta$ 's) in the model presented in Figure 1. Composite scores were corrected for scale unreliability in Protestants and Catholics separately using the measurement model estimates of the factor loadings. Construct reliability for each composite was calculated using Fornell and Larker's approach (1981), cited as:

Construct reliability $=(\Sigma$ standarised loading $)^{2} /\left[\left(\sum \text { standarised loading }\right)^{2}+\Sigma \varepsilon_{j}\right]$

where $\varepsilon_{j}=$ the measurement error for each indicator and the standardised loadings are obtained directly from the LISREL program output from the initial measurement models.

Since latent constructs were computed as summated scales indicated by one total score, the data were treated as continuous and estimation of the path coefficients was performed using Maximum Likelihood (ML) methods based on separate covariance matrices for Protestants and Catholics. Model fit was again assessed using the SatorraBentler (S-B $\chi^{2}$ ), the Root Mean Square Error of Approximation (RMSEA) with $90 \%$ confidence intervals. The comparative fit of the models was assessed using the Expected Cross Validation Index (ECVI), the Compara- 
tive Fit Index (CFI) - indices used for the purposes of model comparison. Figure 1 presents a theoretical model of the inter-relationships among the latent constructs. The adequacy of this model was tested for invariance in the measurement and structural parameters across the two main religious groupings using a strategy based on modification indices and expected parameter change statistics (Byrne, 1998, p. 338). This took the form of a multi-group analysis involving the simultaneous ML estimation of path coefficients for both groups. Model adequacy was assessed using a fitting function representing a weighted combination of model fit across groups (Bollen, 1989). The testing strategy initially involved using the $\chi^{2}$ difference statistic (symbolised as $\triangle \chi_{(\mathrm{df})}^{2}$ ) to test for measurement invariance across the religious groupings in terms of the factor structure, the pattern of loadings and the structural paths between the constructs specified in Figure 1.

\section{RESULTS}

\section{Measurement Models}

Table 1 presents the loading estimates from a 7-factor confirmatory factor analytic model that included all perceptual items. With the exception of three GHQ-12 item loadings on the negative item "method factor", all factor loadings were statistically significant for both groups $(\mathrm{p}<0.05)$. Construct reliabilities for each of the scales using Hair et al.'s (1998, p. 612) formula are presented in Table 2 and significance tests of group differences on the constructs is tests are presented in Table 3.

Table 1. Standardised factor loading estimates using ML for a combined Catholic and Protestant measurement model

\begin{tabular}{|c|c|c|c|c|}
\hline & Items & \multicolumn{3}{|c|}{ Standardised loadings } \\
\hline & GHQ-12 & $\begin{array}{c}\text { General } \\
\text { factor }\end{array}$ & $\begin{array}{c}\text { Positive } \\
\text { method } \\
\text { factor }\end{array}$ & $\begin{array}{c}\text { Negative } \\
\text { method } \\
\text { factor }\end{array}$ \\
\hline \multicolumn{5}{|c|}{ Positive items - Have you recently ... } \\
\hline 1. & $\begin{array}{l}\text { Been able to concentrate on what you were } \\
\text { doing? }\end{array}$ & .49 & .39 & \\
\hline 2. & Lost much sleep over worry? & .35 & .61 & \\
\hline 3. & $\begin{array}{l}\text { Felt that you are playing a useful part in } \\
\text { things? }\end{array}$ & .34 & .76 & \\
\hline 4. & $\begin{array}{l}\text { Felt capable about making decisions about } \\
\text { things? }\end{array}$ & .51 & .53 & \\
\hline 5. & Felt constantly under strain? & .42 & .61 & \\
\hline 6. & Felt you couldn't overcome your difficulties? & .52 & .50 & \\
\hline
\end{tabular}

Table continues 
Table 1 (continued)

\begin{tabular}{|c|c|c|c|}
\hline \multicolumn{4}{|c|}{ Negative items - Have you recently ... } \\
\hline 7. & $\begin{array}{l}\text { Been able to enjoy your normal day-to-day } \\
\text { activities? }\end{array}$ & .70 & $.11 *$ \\
\hline 8. & Been able to face up to your problems? & .88 & $-.07 *$ \\
\hline 9. & Been feeling unhappy and depressed? & .83 & $.14 *$ \\
\hline 10. & Been losing confidence in yourself? & .81 & .27 \\
\hline 11. & $\begin{array}{l}\text { Been thinking of yourself as a worthless } \\
\text { person? }\end{array}$ & .76 & .58 \\
\hline 12. & $\begin{array}{l}\text { Been feeling reasonably happy, all things } \\
\text { considered? }\end{array}$ & .68 & .51 \\
\hline \multicolumn{4}{|c|}{ Ethnic density } \\
\hline 13. & $\begin{array}{l}\text { How many of your close neighbours are of a } \\
\text { different religion to you? }\end{array}$ & .58 & \\
\hline 14. & $\begin{array}{l}\text { In the area where you live, how many of the } \\
\text { people do you think are of a different religion? }\end{array}$ & .83 & \\
\hline 15. & $\begin{array}{l}\text { How often do you see members of the 'other' } \\
\text { community in this area? }\end{array}$ & .58 & \\
\hline 16. & $\begin{array}{l}\text { Guess what percentage of people in the areas } \\
\text { where you live are of the Protestant/Catholic. }\end{array}$ & .78 & \\
\hline \multicolumn{4}{|c|}{ Socio-economic status } \\
\hline 17. & Standard Occupational Classification (SOC) & .46 & \\
\hline 18. & Income & .87 & \\
\hline \multicolumn{4}{|c|}{ In-group identification } \\
\hline 19. & $\begin{array}{l}\text { Considers the Catholic / Protestant community } \\
\text { important? }\end{array}$ & .81 & \\
\hline 20. & $\begin{array}{l}\text { Identifies with the Catholic / Protestant } \\
\text { community? }\end{array}$ & .91 & \\
\hline 21. & $\begin{array}{l}\text { Feels strong ties with the Catholic / Protestant } \\
\text { community? }\end{array}$ & .92 & \\
\hline 22. & $\begin{array}{l}\text { Is glad to belong to the Catholic / Protestant } \\
\text { community? }\end{array}$ & .96 & \\
\hline 23. & $\begin{array}{l}\text { Sees him/herself as belonging to the Catholic / } \\
\text { Protestant community? }\end{array}$ & .94 & \\
\hline \multicolumn{4}{|c|}{ Perceived discrimination } \\
\hline 24. & $\begin{array}{l}\text { The way jobs are distributed between the two } \\
\text { main communities in Northern Ireland. }\end{array}$ & .86 & \\
\hline 25. & The way political power is distributed. & .76 & \\
\hline 26. & $\begin{array}{l}\text { The relative standard of living of one's own } \\
\text { community relative to the 'other community'. }\end{array}$ & 63 & \\
\hline
\end{tabular}


Table 2. Descriptive statistics on summated variables

\begin{tabular}{|c|c|c|c|c|c|c|}
\hline Summated scales & Religion & $\begin{array}{l}\text { Construct } \\
\text { reliability }\end{array}$ & $\mathrm{N}$ & Mean & $\mathrm{SD}$ & $\begin{array}{c}\text { Significance } \\
\text { of mean } \\
\text { differences }\end{array}$ \\
\hline \multirow{2}{*}{ SES } & Protestant & 0.727 & 438 & 6.95 & 2.68 & \multirow{2}{*}{$\mathrm{p}<0.001$} \\
\hline & Catholic & 0.603 & 382 & 6.28 & 2.53 & \\
\hline \multirow{2}{*}{$\begin{array}{l}\text { Perceived ethnic } \\
\text { density }\end{array}$} & Protestant & 0.777 & 480 & 12.97 & 2.73 & \multirow{2}{*}{$\mathrm{p}=0.077$} \\
\hline & Catholic & 0.833 & 412 & 13.31 & 2.89 & \\
\hline \multirow{2}{*}{$\begin{array}{l}\text { In-group } \\
\text { identification }\end{array}$} & Protestant & 0.953 & 480 & 18.38 & 5.81 & \multirow{2}{*}{$\mathrm{p}=0.001$} \\
\hline & Catholic & 0.975 & 412 & 19.55 & 5.00 & \\
\hline \multirow{2}{*}{$\begin{array}{l}\text { Perceived } \\
\text { discrimination }\end{array}$} & Protestant & 0.954 & 480 & 8.06 & 2.56 & \multirow{2}{*}{$\mathrm{p}<0.001$} \\
\hline & Catholic & 0.876 & 412 & 7.44 & 2.57 & \\
\hline \multirow{2}{*}{ GHQ-12 } & Protestant & 0.974 & 480 & 10.36 & 5.17 & \multirow{2}{*}{$\mathrm{p}=0.233$} \\
\hline & Catholic & 0.881 & 412 & 9.93 & 5.55 & \\
\hline
\end{tabular}

Table 3. Zero-order correlations among summated perceptual scales and GHQ-12 scores for Protestants and Catholics separately

\begin{tabular}{|c|c|c|c|c|c|}
\hline & SES & $\begin{array}{c}\text { Perceived } \\
\text { ethnic density }\end{array}$ & $\begin{array}{c}\text { In-group } \\
\text { identification }\end{array}$ & $\begin{array}{c}\text { Perceived } \\
\text { discrimination }\end{array}$ & GHQ-12 \\
\hline SES & 1 & $\begin{array}{l}-0.054 \\
(438)\end{array}$ & $\begin{array}{l}-0.084 \\
(438)\end{array}$ & $\begin{array}{l}-0.028 \\
(438)\end{array}$ & $\begin{array}{l}-0.193^{*} \\
(438)\end{array}$ \\
\hline $\begin{array}{l}\text { Perceived } \\
\text { ethnic density }\end{array}$ & $\begin{array}{l}-0.165 * * \\
(382)\end{array}$ & 1 & $\begin{array}{l}0.124 * * \\
(480)\end{array}$ & $\begin{array}{l}0.155^{* *} \\
(480)\end{array}$ & $\begin{array}{l}0.103^{*} \\
(480)\end{array}$ \\
\hline $\begin{array}{l}\text { In-group } \\
\text { identification }\end{array}$ & $\begin{array}{l}-0.093 \\
(382)\end{array}$ & $\begin{array}{l}0.129 * * \\
(412)\end{array}$ & 1 & $\begin{array}{l}0.151^{* *} \\
(480)\end{array}$ & $\begin{array}{l}0.041 \\
(480)\end{array}$ \\
\hline $\begin{array}{l}\text { Perceived } \\
\text { discrimination }\end{array}$ & $\begin{array}{c}0.053 \\
(382)\end{array}$ & $\begin{array}{l}-0.067 \\
(412)\end{array}$ & $\begin{array}{c}0.060 \\
(412)\end{array}$ & 1 & $\begin{array}{l}0.140^{* *} \\
(480)\end{array}$ \\
\hline GHQ-12 & $\begin{array}{l}-0.109^{*} \\
(382)\end{array}$ & $\begin{array}{l}-0.064 \\
(412)\end{array}$ & $\begin{array}{l}0.008 \\
(412)\end{array}$ & $\begin{array}{l}0.291 * * \\
(412)\end{array}$ & 1 \\
\hline
\end{tabular}

Note: Correlations for Protestants are recorded above the diagonal. Catholics are recorded below the diagonal.

$* \mathrm{p}<.05$ (one-tailed), $* * \mathrm{p}<.01$ (one-tailed)

\section{Religious Differences on Summated Scales}

Table 3 presents descriptive statistics for Protestants and Catholics separately. The
Protestant grouping scored significantly higher on the SES scale than Catholics. Protestants also scored higher on perceived ingroup discrimination but Catholics scored higher on in-group identification. 


\section{Zero Order Correlations among Summated Scales}

Zero order correlations for all summated scales (Table 3) show that SES is significantly negatively correlated with GHQ-12 scores for both Protestants and Catholics. Similarly, perceptions of inequality are positively related to GHQ-12 total scores for both religious groups. However, for the Protestants sampled, higher perceived own group density was significantly related to higher ingroup identification, greater perceptions of discrimination/inequality and lower psychological adjustment as measured by the GHQ12. For Catholics, perceptions of own group density were associated with higher in-group identification, but were not related to perceived inequality or psychological adjustment. Indeed, in-group identification was moderately associated with perceived inequality in the Protestant sample, but not in the Catholic sample.

\section{Measurement Invariance Across Groups}

The measurement model was then assessed simultaneously for Protestants and Catholics. Table 4 compares nested measurement models for the combined sample with no equality constraints across groups (model $1)$, equality imposed on all factor loadings across groups (model 2) and a final fitted model relaxing some parameters across groups (model 3) on the basis of modification indices and expected change statistics. Model 3 achieved adequate fit by specifying an error covariance term in the Protestant model (group identification items 22 and $20)$, adding an error covariance term for the Catholic group (GHQ items 6 and 4), as well as two additional loading terms (GHQ item 3 on the negative item "method" factor and GHQ item 11 on the positive item "method" factor). The fit of model 3 was not significantly different to model $1\left(\triangle \mathrm{S}-\mathrm{B} \chi_{(34)}^{2}=\right.$ $43.42, \mathrm{p}>0.05$ ), demonstrating group invariance in terms of the underlying factor structure and in the factor loadings.

\section{Invariance in Paths Across Groups}

A hypothetical model (Figure 1) was fitted simultaneously to the Protestant and Catholic samples to allow for tests of invariance on all possible paths. Table 4 provides nested model comparisons for the combined sample with no equality constraints on the structural paths (model 4), equality imposed on all paths across groups (model 5) and a final fitted model relaxing some parameters across groups (model 6) on the basis of modification indices and expected change statistics. Model 6 achieved adequate fit by freeing the equality constraints on the paths from ethnic density to perceived discrimination and the path from perceived discrimination to GHQ-12 (S-B $\chi^{2}=8.68, \mathrm{df}=9, \mathrm{p}=0.47$, RMSEA $<0.054)$. The fit of model 6 was not statistically different from the unconstrained model $4\left(\triangle \mathrm{S}-\mathrm{B} \chi_{(7)}^{2}=3.11, \mathrm{p}>0.05\right)$.

In summary, the best fitting combined model exhibited invariance in the direct structural relations between SES and ethnic density, SES and GHQ-12, ethnic density and ingroup identification, ethnic density and GHQ-12 and identification and perceived discrimination. Group differences were evident on two direct paths, namely the relationship between ethnic density perceptions and feelings of discrimination and in the path between perceived discrimination and GHQ-12. All paths with the exception of two (SES to 
Table 4. Comparison of fit indices for measurement and path models

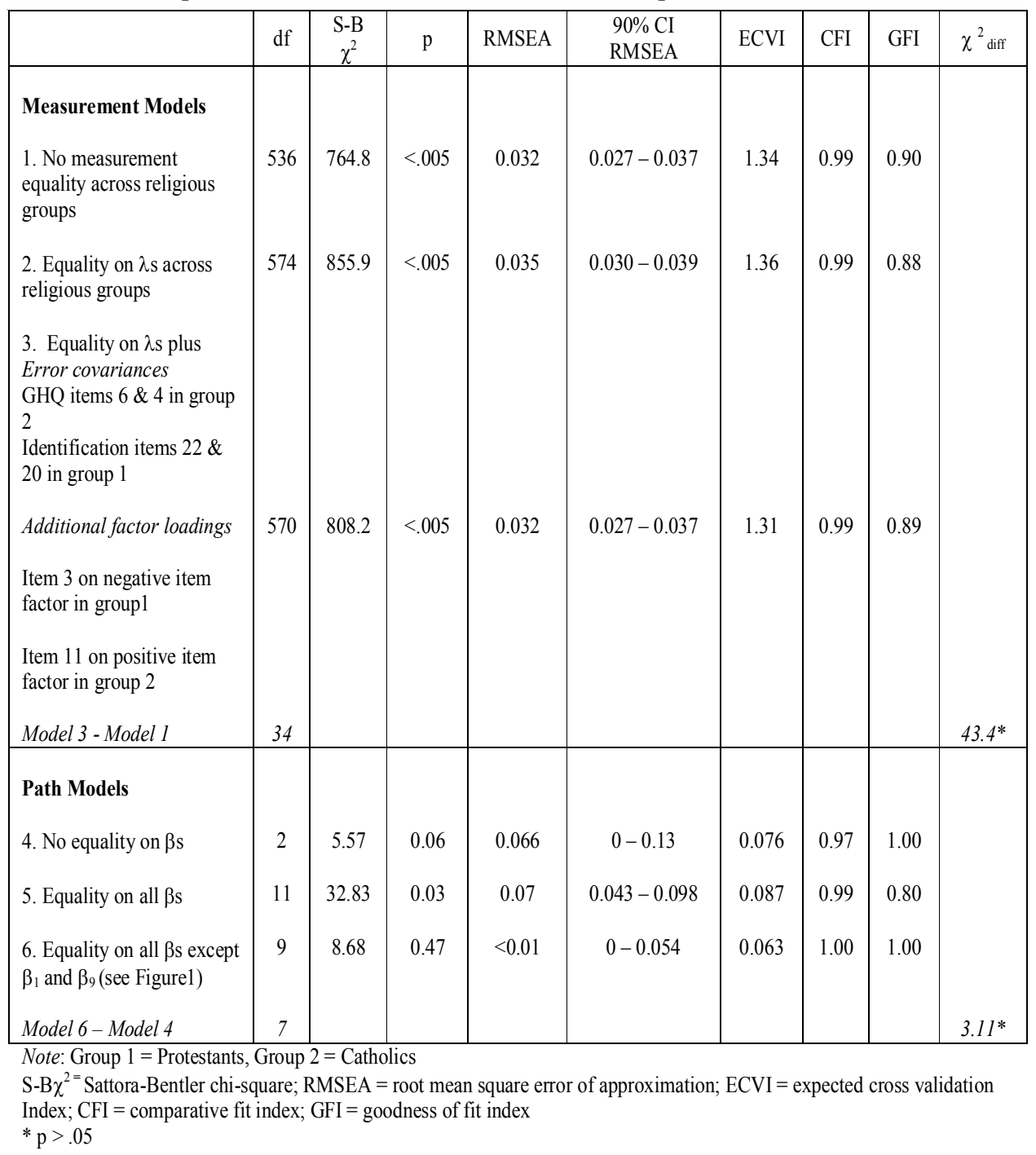

perceived discrimination and group identification to GHQ-12) were statistically significant $(p<.05)$. Notably, non-significance was evident in both religious groupings. Figure 2 shows the standardised parameter estimates for each path.
Specifying the interaction term (identification $\mathrm{x}$ density) using centred variables resulted in a non-significant path to GHQ scores $(p>0.05)$. This term was therefore not included in the model. The indirect effects of SES and perceived ethnic density 


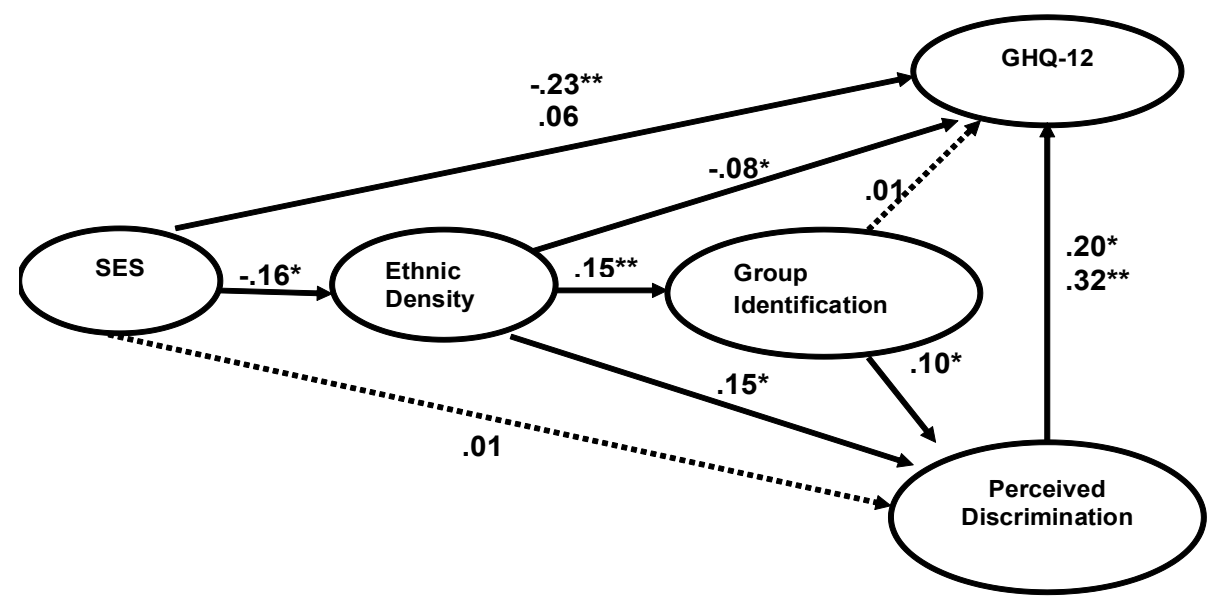

Figure 2. Standardised path coefficients of the influence of SES, ethnic density, group identification and perceived discrimination on GHQ-12 for Protestants $(\mathrm{n}=438)$ and Catho$\operatorname{lics}(\mathrm{n}=382)^{1}$

on GHQ via group identification, perceived discrimination were also assessed. All of these effects were non-significant $(\mathrm{p}>0.05)$.

\section{DISCUSSION}

This study demonstrated a significant, group invariant effect of SES on psychological wellbeing, which is consistent with previous work linking SES to various health outcomes (e.g., Kennedy et al., 1998; Ross, 2000). The data, however, has also provided evidence for small direct and indirect "ethnic density effects" in both ethno-religious groups in Northern Ireland $(\beta=-.08$, see Fig-

\footnotetext{
${ }^{1}$ For each path, $\beta$ s for Protestants are inserted directly above the Catholic estimates. Where one estimate appears, $\beta$ s are equal across groups.

$*$ indicates $\mathrm{p}<0.05,{ }^{* *}$ indicates $\mathrm{p}<0.01$. Broken line indicates a non-significant path.
}

ure 1). Karlsen et al. (2002) have argued that the inter-relationship between socio-economic and ethnic inequalities in health may actually disguise any "ethnic density effect". Ethnic residential concentration can be seen as both a symptom of economic disadvantage and a mechanism by which such disadvantaged can be buffered. Thus, any psychological buffering may offset the negative consequences of lower socio-economic status. Even controlling for SES, a small "ethnic density effect" was still present.

It is useful to view "ethnic density" and "intergroup contact" are theoretically different, but inter-related constructs. Greater ingroup ethnic density may restricting opportunities for intergroup contact, but other factors besides variability in ethnic density will determine the degree of direct contact experiences with in-group and out-group members (Neesdale, Todd, 1998, p. 1209). 
Karlsen et al. (2002) have argued that a key feature of the relationship between ethnicity, health and residential environment, is the way in which ethnic identification may lead to a stronger sense of community, which in turn offers psychological protection to those living in areas where large numbers share that same identity. In the current study, in-group identification did not exert a moderating influence on the relationship between ethnic density and psychological health. There was a small direct relationship between ethnic density and psychological health, regardless of whether in-group identification was strong or weak.

The findings of this study differed somewhat from Postmes and Branscombe (2002) who reported a direct link between levels of in-group identification and psychological wellbeing. Ethno-cultural differences may account for differences in the expressed levels of in-group identification in whiteand nonwhitegroups. For example, expressed pride in being black may be more acceptable among black communities than expressed pride in being white within white or mixed communities due to allegations of racism. This study employed an ostensibly all white sample. Postmes and Branscombe (2002) employed the 10-item Rosenberg Personal Self-Esteem Inventory (PSE; Rosenberg, 1965), and although the Rosenberg PSE and GHQ-12 are highly correlated (Tait, French, Hulse, 2003), the two instruments are designed to assess conceptually unique components of wellbeing. Finally, Postmes and Branscombe (2002) measured racial composition as a lifespan measure, with three of the five questions relating to past events and none relating to residential segregation. Bycontrast, this study examined three aspects of perceptions of ethnic residential segregation.
Despite broadly similar results from both religious groupings, some differences did emerge. For Protestants, high levels of perceived in-group density were associated with stronger perceptions of discrimination, which in turn were related to lower levels of psychological wellbeing. In contrast, for Catholics, higher in-group density was associated with lower perceived discrimination. Protestants also expressed higher mean levels of perceived discrimination/inequality than Catholics $(p<0.001)$. One explanation may be that these perceptions in the Protestant sample are linked to feelings of minority group status, despite the fact that Protestants currently form the numerical majority over Catholics in Northern Ireland and the finding that the SES was significantly higher overall in the Protestant sample. This is either suggestive of a buffering mechanism among Catholics or a political context in which Protestants living in segregated Protestant areas have reported higher feelings of inequality and grievance than their Catholic counterparts. It is not possible in this study to separate out any possible differential effects of in-group psychological protection across the two main ethno-religious groups from differing perceptions of the political context and in-group status in segregated areas. Given that there were no overall differences in psychological wellbeing between the two ethno-religious groups in Northern Ireland (Table 2), this suggests a political context in which feelings of inequality and discrimination were felt most strongly in segregated Protestant communities during the period of data collection (April/May 2001).

This study was limited to perceptions of residential segregation and future studies should take account of the multi-faceted na- 
ture of integration, such as in education, marriage, work, sport, etc. (Niens, Cairns, Hewstone, 2003). And given this study was limited to the measurement of individual perceptions, the advances in geographic modelling techniques now make it more routinely possible for researchers to study structural and perceptual variables separately or in combination at small area level in order to monitor temporal changes in the strength or weakness of an "ethnic density effect". Monitoring could therefore provide a useful additional indication of the success of community relations policies aimed at promoting integration in Northern Ireland and elsewhere. Policies aimed at creating environments and contexts in which integration is psychologically rewarding are therefore ultimately aimed at eradication of the "ethnic density effect"

Received April 8, 2013

\section{REFERENCES}

ALLPORT, G.W., 1954, The nature of prejudice. Cambridge, MA: Addison-Wesley.

BÉCARES, L., NAZROO, J.Y., STAFFORD, M., 2009, The buffering effects of ethnic density on experienced racism and health. Health \& Place, 15, 3, 670-678.

BÉCARES, L., SHAW, R., NAZROO, J. STAFFORD, M., ALBOR, C., ATKIN, K., et al., 2012, Ethnic Density effects on physical morbidity, mortality and health behaviors: A systematic review of the literature. American Journal of Public Health, 102, 12, 33-36.

BOLLEN, K.A., 1989, Structural equations with latent variables. New York, NY: Wiley.

BOYDELL, J., van OS, J., MCKENZIE, K., ALLARDYCE, J., GOEL, R., MCCREADIE, R.G. et al., 2001, Incidence of schizophrenia in ethnic minorities in London: Ecological study into interactions with environment. British Medical Journal, 323, 7325, 1336-1336.

BRANSCOMBE, N.R., SCHMITT, M.T., HARVEY, R.D., 1999, Perceiving pervasive dis- crimination among African Americans: Implications for group identification and wellbeing. Journal of Personality and Social Psychology, 77, 135149 .

BROWN, R.J., CONDOR, S., MATHEWS, A., WADE, G., WILLIAMS, J.A., 1986, Explaining intergroup differentiation in an industrial organization. Journal of Occupational Psychology, 59, 273286.

BYRNE, B., 1998, Structural equation modelling with LISREL, PRELIS and SIMPLIS: Basic concepts, applications and programming. London, UK: Lawrence Erlbaum Associates.

CAIRNS, E., 1988, Class, psychological wellbeing and minority status in Northern Ireland. The International Journal of Social Psychiatry, 35, 3, 231236.

CAIRNS, E., HEWSTONE, M., 2002, The impact of peace making in Northern Ireland on intergroup behaviour. In: G. Salomon, B. Nevo (Eds.), The nature and study of peace education (pp. 217228). Hillsdale, NJ: Erlbaum.

DIENER, E., SUH, E.M., LUCAS, R.E., SMITH, L., 1999, Subjective wellbeing: Three decades of progress. Psychological Bulletin, 125, 276-302.

FARIS, R.E., DUNHAM, H.W., 1939, Mental disorder in urban areas. Chicago, IL: University of Chicago Press.

FORNELL, C., LARKER, D.F., 1981, Evaluating structural equation models with unobservable variables and measurement error. Journal of Marketing Research, 18, 39-50.

GALLAGHER, A.M., 1989, Social identity and the Northern Ireland conflict. Human Relations, 42, 10, 917-935.

GOLDBERG, D.P., WILLIAMS, P., 1988, A user's guide to the General Health Questionnaire. Windsor, UK: NFER-Nelson.

HAIR, J.F., ANDERSON, R.E., TATHAM, R.L., BLACK, W.C., 1998, Multivariate data analysis. (5th ed.). Englewood Cliffs, NJ: Prentice Hall.

HALPERN, D., 1993, Minorities and mental health. Social Science and Medicine, 36, 5, 597607.

HALPERN, D., NAZROO, J., 2000, The ethnic density effect: Results from a national community survey of England and Wales. International Journal of Social Psychiatry, 46, 1, 34-46.

HEWSTONE, M., BROWN, R., 1986, Contact is not enough: An intergroup perspective on the 'contact hypothesis.' In: M. Hewstone, R. Brown (Eds.), Contact and conflict in intergroup encounters (pp. 1-44). Oxford: Basil Blackwell. 
JÖRESKOG, K.G., SÖRBOM, D., 2004, LISREL 8.7: Users reference guide. Chicago, IL: Scientific Software International.

KARLSEN, S., NAZROO, J.Y., STEPHENSON, R., 2002, Ethnicity, environment and health: Putting ethnic inequalities in health in their place. Social Science \& Medicine, 55, 1647-1661.

KESSLER, R., MICKELSON, K., WILLIAMS, D., 1999, The prevalence, distribution and mental health correlates of perceived discrimination in the United States. Journal of Health \& Social Behavior, 40, 3, 208-230.

KENNEDY, B.P., KAWACHI, I., GLASS, R., PROTHROW-STITH, D., 1998, Income distribution, socio-economic status and self-rated health in the United States: Multi-level analysis. British Medical Journal, 317, 917-921.

SAM, D.L., 1998, Predicting life satisfaction among adolescents from immigrant families in Norway. Ethnicity \& Health, 3, 1/2, 5-18.

MAJOR, B., O'BRIEN, L.T., 2005, The social psychology of stigma. Annual Review of Psychology, 56, 393-421.

MALLETT, J., CAIRNS, E., BUNTING, B., 2002, Ethnic density in Northern Ireland. Journal of Community and Applied Social Psychology, 12, 20, 137 141.

NAZROO, J.Y., 1998, Genetic, cultural or socioeconomic vulnerability? Explaining ethnic inequalities in health. Sociology of Health \& Illness, 20, 5, 710-730.

NEELEMAN, J., WESSELY, S., 1999, Ethnic minority suicide: A small area geographical study in South London. Psychological Medicine, 29, 2, 429436

NEESDALE, D., TODD, P., 1998, Inter-group ratio and the contact hypothesis. Journal of Applied Social Psychology, 28, 13, 1196-1217.

NIENS, U., CAIRNS, E., HEWSTONE, M., 2003, Contact and conflict in Northern Ireland. In: $\mathrm{O}$ Hargie, D. Dickson (Eds.), Researching the Troubles: Social science perspectives on the Northern Ireland conflict (pp. 123-140). Edinburgh, UK: Mainstream Publishing.

NISRA, 2001, A profile of Protestants and Roman Catholics in the labour force. Monitor 2/1, Source Book. A Northern Ireland Statistics \& Research Agency Statistical Publication. Belfast: Northern Ireland Statistics \& Research Agency.
POOLE, M., DOHERTY, P., 1996, Ethnic residential segregation in Northern Ireland. Coleraine, UK: Centre for the Study of Conflict, University of Ulster.

PICKETT, K.E., WILKINSON, R.G., 2008, People like us: Ethnic group density effects on health. Ethnic Health, 13, 4, 321-334.

POSTMES, T., BRANSCOMBE, N.R., 2002, Influence of long-term racial environmental composition on subjective wellbeing in African Americans. Journal of Personality and Social Psychology, 83, 735-751.

ROSENBERG, M., 1965, Society and the adolescent self-image. Princeton, NJ: Princeton University Press.

ROSS, C.E., 2000, Neighbourhood disadvantage and adult depression? Journal of Health and Social Behavior, 41, 177-187.

SATORRA, A., BENTLER, P.M., 1988, Scaling corrections for chi-square statistics in covariance structure analysis. ASA Proceedings of the Business and Economic Statistics Section (pp. 308-313). Alexandria, VA: American Statistical Association.

SIGLEMAN, L., WELCH, S., 1991, Black American's view of racial inequality: The dream deferred. New York, NY: Cambridge University Press.

SMAJE, C., 1995, Ethnic residential concentration and health: Evidence for a positive effect? Policy \& Politics, 23, 3, 251-269.

STANDARD OCCUPATIONAL CLASSIFICATION, 2000, UK Office of National Statistics. http:/ /www.ons.gov.uk/ons/guide-method/classifications/ archived-standard-classifications/standard-occupational-classification-2000/about-soc-2000/ index.html

STEIGER, J.H., 1990, Structural model evaluation and modification. An interval estimation approach. Multivariate Behavioral Research, 25, 173180.

TAIT, R.J., FRENCH, D.J., HULSE, G.K., 2003, Validity and psychometric properties of the General Health Questionnaire - 12 in young Australian adolescents. Australian and New Zealand Journal of Psychiatry, 37, 3, 374-381.

TAJFEL, H., TURNER, J.C., 1986, The social identity theory of intergroup behaviour. In: S. Worchel, W.G. Austin (Eds.), The social psychology of intergroup relations (pp. 7-24). Chicago, IL: Nelson- Hall. 


\title{
VNÍMANÁ VNÚTRO SKUPINOVÁ HUSTOTAA PSYCHOLOGICKÁ ADJUSTÁCIASEVEROÍRSKYCH KATOLÍKOVAPROTESTANTOV
}

\author{
J. M a 11 e t, C. A. L e wis, E. C a i r n s
}

Súhrn: Podl'a „hypotézy kontaktu“ je desegregácia dobrá pre členov minoritných skupín, ale tento názor je v rozpore so štúdiami, ktoré opisujú tzv. „efekt etnickej hustoty“. Štúdia skúma „efekt etnickej hustoty“ v kontexte historickej etnicko-náboženskej segregácie v Severnom Írsku. Predpokladali sme, že „efekt etnickej hustoty“ nie je len výsledkom štrukturálnych premenných, akou je etnická zmes populácie na lokálnej úrovni, ale aj individuálneho vnímania miestnej etnicko-náboženskej skupinovej hustoty, vnímania ich lokálneho skupinového postavenia a úrovní ich vnútro skupinovej identifikácie alebo solidarity. Údaje od 1000 náhodne vybraných respondentov sa testovali na etnicko-náboženskú skupinovú invariantnost' pri predikovaní psychologickej adjustácie, meranej General Health Questionnaire (GHQ-12). Výsledky poukázali na malý priamy „efekt etnickej hustoty“ založený na vnímaní náboženskej rozmanitosti na lokálnej úrovni $(\mathrm{p}<.05)$. Pozorovali sme etnicko-náboženské rozdiely vo vzt’ahu medzi vnímanou etnickou hustotou a vnímanou diskrimináciou $(\mathrm{p}<.05)$. „Efekt etnickej hustoty“ spomímaný v niektorých kultúrnych kontextoch bol zjavný v Severnom Írsku a tento poznatok odporúčame do pozornosti politikom, ktorí sa zaujímajú o vzt’ahy v komunitách. 